\title{
Manipulation of Seed Germination and Vigour by Biopriming with Liquid Microbial Cultures in Paddy (Oryza sativa L.)
}

\author{
K. Raja $^{1^{*}}$, K. Sivasubramaniam ${ }^{2}$ and R. Anandham ${ }^{2}$ \\ ${ }^{1}$ Tamil Nadu Rice Research Institute, Tamil Nadu Agricultural University, \\ Aduthurai - 612 101, Tamil Nadu, India \\ ${ }^{2}$ Agricultural College and Research Institute, Tamil Nadu Agricultural University, \\ Madurai - 625 104, Tamil Nadu, India \\ *Corresponding author
}

\section{A B S T R A C T}

\begin{tabular}{|l|}
\hline K e y w o r d s \\
Paddy, PGPB, \\
Biopriming, Seed \\
germination, Vigour, \\
Azospirillum, \\
Phosphobacteria, \\
PPFM, Liquid culture
\end{tabular}

Keywords

Paddy, PGPB,

Biopriming, Seed

Azospirillum,

Phosphobacteria

\section{Introduction}

Seed priming is a treatment applied prior to sowing in a specific environment wherein seeds are partially hydrated to a point of germination process initiation sans visible symptom of radical emergence (Bradford, 1986; Giri and Schilinger, 2003). Primed seeds usually exhibit an increased germination rate, uniformity and greater total germination percentage (Basra et al., 2005) and improved germination under sub-optimal conditions (Lin and Sung, 2001). Bio-priming is a process of biological seed treatment that refers to combination of seed hydration and inoculation of seed with beneficial organism to protect seed and improve the germination. It is an ecological approach using either bacteria or selected fungal antagonists against the soil and seed-borne pathogens. Therefore, biological seed treatments may provide an alternative to chemical control of crop diseases.

Application of inoculum to the seeds of host plants is still in vogue with carrier based bacterial inoculants (Graham et al., 1987). Sometimes in order to improve stickiness on the seed, adhesive is added (Jahuri, 2001). However carrier-based inoculants have a short 
shelf life, poor quality and most of the carrier based inoculants production and application procedure were found to be time consuming and difficult when used for large quantities of seed. Hence, alternate liquid inoculants were developed for seed treatment as it is easy to use, spreads well, mixes easily and needs no additional water supply (Nethery, 1991). The liquid rhizobial inoculant for pea and lentil resulted in yield equal to or better than those obtained for the peat inoculant (Hynes et al., 1995). Gomathy et al., (2008) reported a population density of $5.5 \times 10^{5} \mathrm{cfu}^{\mathrm{c}} \mathrm{seed}^{-1}$ on black gram, $10.5 \times 10^{5} \mathrm{cfu} \mathrm{seed}^{-1}$ on soybean and $6.5 \times 10^{5} \mathrm{cfu}$ seed $^{-1}$ on maize after $12 \mathrm{~h}$ of incubation in $1 \mathrm{ml}$ sporulated inoculum mixed with $1 \mathrm{ml}$ of rice gruel. Biopriming involves coating or soaking seed in slurry of bacterial biocontrol agents such as Pseudomonas, Trichoderma etc (Callan et al., 1990). Hence, a study was conducted to find out the suitable liquid microbial cultures for effective biopriming seed treatment in paddy.

\section{Materials and Methods}

Paddy variety ADT 43 seeds were collected from Vegetable Research Station, Palur (India) and dried well for the purpose of microbial treatments. The bacterial strains viz., Azospirillum, phosphobacteria, Methylobacterium [Pink Pigmented Facultative Methylotroph (PPFM)] were obtained from the Department of Agricultural Microbiology, Agricultural College and Research Institute, Madurai (India). The strains were cultured in $\mathrm{NFb}$, nutrient broth and ammonium mineral salts medium supplemented with $0.5 \%$ methanol. The liquid based bio-inoculant formulations were prepared for treating the seeds. The liquid cultures were diluted at various concentrations viz., 1:1, 1:10, 1:50 and 1:100 dilutions along with undiluted one. Then, the paddy seeds were soaked in these concentrations at different time durations viz.,
$6,12,18$ and $24 \mathrm{~h}$ with equal seed to culture ratio i.e. 1:1 ratio $(\mathrm{v} / \mathrm{v})$. After the priming treatment, the seeds were shade dried to the original moisture. The germination test was conducted as per the ISTA (1999) procedure and evaluated. The speed of germination was also assessed during the germination test (Maguire, 1962). Five randomly selected seedlings in each treatment were measured for its length and mean was arrived.

After standardization of the concentrations, the freshly collected paddy seeds were inoculated with the liquid microbial cultures to assess the storability of the bioprimed seeds as per the treatments viz., $\mathrm{T}_{1}$ - Untreated control; $\mathrm{T}_{2}$ - Seed soaking in Azospirillum liquid culture @1:50 dilution for $24 \mathrm{~h} ; \mathrm{T}_{3}$ Seed soaking in phosphobacteria liquid culture @1:50 dilution for $18 \mathrm{~h}$ and $\mathrm{T}_{4}$ - Seed soaking in PPFM liquid culture @1:100 dilution for $18 \mathrm{~h}$. The seeds were shade dried to the original moisture content and evaluated for its initial germination. Then, the seeds were packed in polythene bags and stored under ambient storage condition for three months. After the storage period, the seeds were evaluated for their viability and vigour. Also, the microbial population in the seeds during initial and after three months storage was assessed. The data collected were subjected to statistical analysis (Panse and Sukhatme, 1967) and the critical difference values were calculated at $5 \%$ probability level.

\section{Results and Discussion}

The inoculation of paddy seeds with PPFM has recorded significant differences among the culture concentration and soaking duration. In which, the seeds soaked in the PPFM culture diluted at 1:10, 1:50 and 1:100 ratios have recorded 100 per cent germination irrespective of the soaking duration. However, the seeds soaked in undiluted culture or $1: 1$ 
dilution have recorded declined germination when it was soaked for more time i.e. 18 or $24 \mathrm{~h}$ (Table 1). Similarly, the speed of germination of the seeds soaked in PPFM culture has showed significant improvement at lower concentrations. The culture concentrations viz., 1:10, 1:50 and 1:100 have recorded the earlier germination at 18 and 24 $\mathrm{h}$ soaking durations. Among these concentrations, 1:100 dilution has performed better with higher speed of germination (22.3) at $24 \mathrm{~h}$ of soaking (Table 1). If the culture concentration is increased, the speed of germination decreased. Particularly the seeds soaked in undiluted culture or $1: 1$ dilution have affected much in the speed of germination. Nevertheless, the seedling vigour has not influenced much by the seed soaking treatment with PPFM culture.

Azospirillum liquid culture seed treatment in paddy has showed significant results in germination and speed of germination. The highest germination $(100 \%)$ and speed of germination (23.7) were recorded in the seeds treated with Azospirillum liquid culture at 1:50 dilution for $18 \mathrm{~h}$ soaking period when compared with control (Table 2). If the seeds soaked in undiluted culture and 1:1 dilution, the germination percentage was reduced to greater extent than the control. The seedling length measured in the seeds treated with Azospirillum @ 1:50 dilution has showed better performance than the control. Similarly, higher germination (88\%) was recorded in the seed treatment with phosphobacteria @1: 50 dilution for $18 \mathrm{~h}$ soaking period when compared with untreated control $(80 \%)$ (Table 3). The negative effect on seed germination was recorded when the seeds soaked in undiluted culture irrespective of the soaking periods. In this case, lowest germination (54\%) was recorded in the seed soaking treatment with undiluted culture for $24 \mathrm{~h}$. Seed treatment with 1:1 dilution has also showed decreased germination. Speed of germination (13.3) and seedling length (34.7 $\mathrm{cm})$ were higher in the seed soaking treatment with phosphobacteria@1:50 diluted liquid culture for $18 \mathrm{~h}$. The lower speed of germination and seedling growth were observed in the higher liquid concentrations viz., undiluted and 1:1 diluted cultures.

Among the different liquid cultures, paddy seeds treated with PPFM liquid culture @ 1:100 dilution for $18 \mathrm{~h}\left(\mathrm{~T}_{4}\right)$ have showed higher germination (91 \%), speed of germination (14.3) and seedling length (33.9 $\mathrm{cm})$ when compared with control and other cultures (Table 4). Seed soaking in Azospirillum liquid culture @ 1:50 dilution for $18 \mathrm{~h}$ has also showed the lengthier seedlings $(34.2 \mathrm{~cm})$ with slight improvement in germination $(87 \%)$. Also, the germination and seedling vigour were not significantly reduced over the period of three months storage in all the treatments. Among the bacterial cultures, phosphobacteria has recorded the maximum population $\left(12 \times 10^{5}\right.$ CFU $\mathrm{g}^{-1}$ of seed) in the paddy seed and PPFM has recorded the minimum $\left(8 \times 10^{4} \mathrm{CFU} \mathrm{g}^{-1}\right.$ of seed). In addition, marginal decline in the microbial population of the seed was recorded during the three months storage (Table 4). However, the population range between $2 \mathrm{x}$ $10^{4}$ and $9 \times 10^{5} \mathrm{CFU} \mathrm{g}{ }^{-1}$ of seed was observed in the bacterial cultures. The available seed moisture might have supported the viability of the microorganisms in the seed. Therefore, seed soaking in liquid microbial culture has the benefit of penetration and survival in the seed. Similar findings of enhanced seed germination by seed coating or seed inoculum of methylotrophs were recorded earlier (Anita, 2010 and Meena et al., 2012). Nkpwatt et al., (2006) found that the cell-free supernatant of the Methylobacterium bacterial culture stimulated germination, suggesting the production of a growth-promoting agent by the methylotroph. 


\section{Int.J.Curr.Microbiol.App.Sci (2017) 6(10): 1612-1618}

Table.1 Effect of seed biopriming with PPFM liquid culture on germination and vigour in paddy

\begin{tabular}{|c|c|c|c|c|c|c|c|c|c|c|c|c|c|c|c|}
\hline \multirow[t]{2}{*}{ Treatments } & \multicolumn{5}{|c|}{ Seed germination $(\%)$} & \multicolumn{5}{|c|}{ Speed of germination } & \multicolumn{5}{|c|}{ Seedling length $(\mathrm{cm})$} \\
\hline & $6 \mathrm{~h}$ & $12 \mathrm{~h}$ & $18 \mathrm{~h}$ & $24 \mathrm{~h}$ & Mean & $6 \mathrm{~h}$ & $12 \mathrm{~h}$ & $18 \mathrm{~h}$ & $24 \mathrm{~h}$ & Mean & $6 \mathrm{~h}$ & $12 \mathrm{~h}$ & $18 \mathrm{~h}$ & $24 \mathrm{~h}$ & Mean \\
\hline Untreated control & 100 & 100 & 100 & 100 & 100.0 & 10.2 & 10.2 & 10.2 & 10.2 & 10.2 & 31.3 & 31.3 & 31.3 & 31.3 & 31.3 \\
\hline Seed soaking in water & 100 & 100 & 98 & 98 & 99.0 & 14.0 & 14.6 & 15.9 & 17.5 & 15.5 & 31.4 & 30.0 & 29.3 & 30.4 & 30.3 \\
\hline $\begin{array}{l}\text { Seed soaking in PPFM @ } \\
100 \% \text { concentration }\end{array}$ & 100 & 100 & 94 & 86 & 95.0 & 10.4 & 13.5 & 10.8 & 10.2 & 11.2 & 30.8 & 29.3 & 31.5 & 29.7 & 30.3 \\
\hline $\begin{array}{l}\text { Seed soaking in PPFM @ } \\
1: 1 \text { dilution }\end{array}$ & 100 & 100 & 97 & 96 & 98.2 & 14.5 & 14.4 & 14.2 & 14.0 & 14.3 & 30.9 & 31.0 & 32.7 & 30.0 & 31.1 \\
\hline $\begin{array}{l}\text { Seed soaking in PPFM @ } \\
\text { 1:10 dilution }\end{array}$ & 100 & 100 & 100 & 100 & 100.0 & 14.2 & 17.6 & 19.6 & 19.4 & 17.7 & 32.3 & 32.0 & 32.8 & 31.7 & 32.2 \\
\hline $\begin{array}{l}\text { Seed soaking in PPFM @ } \\
\text { 1:50 dilution }\end{array}$ & 100 & 100 & 100 & 100 & 100.0 & 15.2 & 18.8 & 19.5 & 20.2 & 18.4 & 32.0 & 33.3 & 31.5 & 31.6 & 32.1 \\
\hline $\begin{array}{l}\text { Seed soaking in PPFM @ } \\
1: 100 \text { dilution }\end{array}$ & 100 & 100 & 100 & 100 & 100.0 & 16.2 & 20.4 & 21.0 & 22.3 & 20.0 & 33.0 & 33.8 & 34.5 & 32.9 & 33.6 \\
\hline Mean & 100.0 & 100.0 & 98.4 & 97.1 & & 13.5 & 15.6 & 15.9 & 16.3 & & 31.7 & 31.5 & 31.9 & 31.1 & \\
\hline & \multicolumn{2}{|c|}{ Treatment } & Duration & \multicolumn{2}{|c|}{$\mathrm{T} \times \mathrm{D}$} & \multicolumn{2}{|c|}{ Treatment } & Duration & \multicolumn{2}{|c|}{$\mathrm{T} \times \mathrm{D}$} & \multicolumn{2}{|c|}{ Treatment } & \multicolumn{2}{|c|}{ Duration } & $\mathrm{T} \times \mathrm{D}$ \\
\hline SEd & \multicolumn{2}{|c|}{0.5} & 0.7 & \multicolumn{2}{|c|}{1.4} & \multicolumn{2}{|c|}{0.06} & 0.04 & \multicolumn{2}{|c|}{0.12} & \multicolumn{2}{|c|}{0.8} & \multicolumn{2}{|c|}{0.6} & 1.6 \\
\hline $\mathrm{CD}(\mathrm{P}=0.05)$ & \multicolumn{2}{|c|}{1.1} & 1.5 & \multicolumn{2}{|c|}{2.9} & \multicolumn{2}{|c|}{0.13} & 0.09 & \multicolumn{2}{|c|}{0.25} & & & \multicolumn{2}{|c|}{ NS } & NS \\
\hline
\end{tabular}

Table.2 Effect of seed biopriming with Azospirillum liquid culture on germination and vigour in paddy

\begin{tabular}{|c|c|c|c|c|c|c|c|c|c|c|c|c|c|c|c|}
\hline \multirow[t]{2}{*}{ Treatments } & \multicolumn{5}{|c|}{ Seed germination $(\%)$} & \multicolumn{5}{|c|}{ Speed of germination } & \multicolumn{5}{|c|}{ Seedling length $(\mathrm{cm})$} \\
\hline & $6 \mathrm{~h}$ & $12 \mathrm{~h}$ & $18 \mathrm{~h}$ & $24 \mathrm{~h}$ & Mean & $6 \mathrm{~h}$ & $12 \mathrm{~h}$ & $18 \mathrm{~h}$ & $24 \mathrm{~h}$ & Mean & $6 \mathrm{~h}$ & $12 \mathrm{~h}$ & $18 \mathrm{~h}$ & $24 \mathrm{~h}$ & Mean \\
\hline Untreated control & 92 & 92 & 92 & 92 & 92.0 & 12.9 & 12.9 & 12.9 & 12.9 & 12.9 & 27.5 & 27.5 & 27.5 & 27.5 & 27.5 \\
\hline Seed soaking in water & 94 & 92 & 92 & 89 & 91.7 & 16.8 & 16.5 & 14.5 & 14.6 & 15.6 & 29.2 & 30.0 & 33.8 & 27.3 & 30.0 \\
\hline $\begin{array}{l}\text { Seed soaking in Azospirillum @ 100\% } \\
\text { concentration }\end{array}$ & 92 & 82 & 84 & 84 & 85.5 & 15.7 & 19.6 & 21.2 & 19.6 & 19.0 & 30.3 & 26.2 & 29.9 & 28.0 & 28.6 \\
\hline $\begin{array}{l}\text { Seed soaking in Azospirillum @ 1:1 } \\
\text { dilution }\end{array}$ & 94 & 90 & 91 & 90 & 91.2 & 18.2 & 21.1 & 19.2 & 20.5 & 19.7 & 28.5 & 26.6 & 26.6 & 27.5 & 27.3 \\
\hline $\begin{array}{l}\text { Seed soaking in Azospirillum @ 1:10 } \\
\text { dilution }\end{array}$ & 88 & 92 & 91 & 90 & 90.2 & 15.7 & 20.9 & 22.2 & 19.1 & 19.5 & 31.0 & 30.6 & 29.7 & 30.6 & 30.5 \\
\hline $\begin{array}{l}\text { Seed soaking in Azospirillum @ 1:50 } \\
\text { dilution }\end{array}$ & 100 & 100 & 100 & 94 & 98.5 & 17.9 & 20.1 & 23.7 & 20.2 & 20.5 & 28.1 & 31.3 & 31.6 & 32.9 & 31.0 \\
\hline $\begin{array}{l}\text { Seed soaking in Azospirillum @ 1:100 } \\
\text { dilution }\end{array}$ & 91 & 90 & 100 & 96 & 94.5 & 12.4 & 17.8 & 19.4 & 20.3 & 17.4 & 30.0 & 26.1 & 27.5 & 31.6 & 28.8 \\
\hline Mean & 93.0 & 91.1 & 92.8 & 90.7 & & 15.6 & 18.4 & 19.0 & 18.2 & & 29.2 & 28.3 & 29.5 & 29.3 & \\
\hline & \multicolumn{2}{|c|}{ Treatment } & Duratiol & & $\mathrm{xD}$ & \multicolumn{2}{|c|}{ Treatment } & Duratio & & $\mathrm{TxD}$ & \multicolumn{2}{|c|}{ Treatment } & Duratio & \multicolumn{2}{|c|}{ TxD } \\
\hline SEd & \multicolumn{2}{|c|}{1.9} & 1.4 & \multicolumn{2}{|c|}{3.8} & \multicolumn{2}{|c|}{0.5} & 0.4 & \multicolumn{2}{|r|}{1.0} & \multirow{2}{*}{\multicolumn{2}{|c|}{$\begin{array}{l}1.4 \\
2.8\end{array}$}} & 1.0 & \multirow{2}{*}{\multicolumn{2}{|c|}{$\begin{array}{l}2.8 \\
\text { NS }\end{array}$}} \\
\hline $\mathrm{CD}(\mathrm{P}=0.05)$ & \multicolumn{2}{|c|}{3.8} & NS & \multicolumn{2}{|c|}{ NS } & \multicolumn{2}{|c|}{1.0} & 0.8 & \multicolumn{2}{|r|}{2.1} & & & NS & & \\
\hline
\end{tabular}




\section{Int.J.Curr.Microbiol.App.Sci (2017) 6(10): 1612-1618}

Table.3 Effect of seed biopriming with phosphobacterial liquid culture on germination and vigour in paddy

\begin{tabular}{|c|c|c|c|c|c|c|c|c|c|c|c|c|c|c|c|}
\hline \multirow[t]{2}{*}{ Treatments } & \multicolumn{5}{|c|}{ Seed germination $(\%)$} & \multicolumn{5}{|c|}{ Speed of germination } & \multicolumn{5}{|c|}{ Seedling length $(\mathrm{cm})$} \\
\hline & $6 \mathrm{~h}$ & $12 \mathrm{~h}$ & $18 \mathrm{~h}$ & $24 \mathrm{~h}$ & Mean & $6 \mathrm{~h}$ & $12 \mathrm{~h}$ & $18 \mathrm{~h}$ & $24 \mathrm{~h}$ & Mean & $6 \mathrm{~h}$ & $12 \mathrm{~h}$ & $18 \mathrm{~h}$ & $24 \mathrm{~h}$ & Mean \\
\hline Untreated control & 80 & 80 & 80 & 80 & 80.0 & 8.9 & 8.9 & 8.9 & 8.9 & 8.9 & 24.0 & 24.0 & 24.0 & 24.0 & 24.0 \\
\hline Seed soaking in water & 72 & 78 & 75 & 76 & 75.3 & 5.8 & 8.1 & 10.9 & 7.4 & 8.0 & 26.0 & 28.3 & 29.7 & 28.1 & 28.0 \\
\hline $\begin{array}{l}\text { Seed soaking in Phosphobacteria @ } \\
100 \% \text { concentration }\end{array}$ & 78 & 68 & 62 & 54 & 65.5 & 7.7 & 4.3 & 4.9 & 3.9 & 5.2 & 27.1 & 29.3 & 31.2 & 31.3 & 29.7 \\
\hline $\begin{array}{l}\text { Seed soaking in Phosphobacteria @ 1:1 } \\
\text { dilution }\end{array}$ & 82 & 79 & 79 & 79 & 79.7 & 8.3 & 9.6 & 10.3 & 9.7 & 9.5 & 30.1 & 29.1 & 30.1 & 29.6 & 29.7 \\
\hline $\begin{array}{l}\text { Seed soaking in Phosphobacteria @ 1:10 } \\
\text { dilution }\end{array}$ & 79 & 85 & 80 & 84 & 82.0 & 8.5 & 12.7 & 11.9 & 8.8 & 10.5 & 31.6 & 29.4 & 28.8 & 25.6 & 28.8 \\
\hline $\begin{array}{l}\text { Seed soaking in Phosphobacteria @ 1:50 } \\
\text { dilution }\end{array}$ & 80 & 80 & 88 & 84 & 83.0 & 7.6 & 12.1 & 13.3 & 13.2 & 11.5 & 28.2 & 28.1 & 34.7 & 31.1 & 30.5 \\
\hline $\begin{array}{l}\text { Seed soaking in Phosphobacteria @ } \\
1: 100 \text { dilution }\end{array}$ & 79 & 80 & 84 & 80 & 80.8 & 7.6 & 11.1 & 12.1 & 9.9 & 10.2 & 29.0 & 30.1 & 31.1 & 30.3 & 30.1 \\
\hline \multirow[t]{2}{*}{ Mean } & 78.4 & 78.4 & 78.2 & 76.6 & 76.9 & 7.7 & 9.5 & 10.4 & 8.8 & 9.0 & 28.0 & 28.3 & 29.9 & 28.5 & \\
\hline & \multicolumn{2}{|c|}{ Treatment } & Duratio & \multicolumn{2}{|c|}{$\mathrm{T} \times \mathrm{D}$} & \multicolumn{2}{|c|}{ Treatment } & Duratio & \multicolumn{2}{|c|}{$\mathrm{T} \times \mathrm{D}$} & \multicolumn{2}{|c|}{ Treatment } & Duratio & \multicolumn{2}{|c|}{$\mathrm{T} \times \mathrm{D}$} \\
\hline & \multicolumn{2}{|c|}{2.8} & 2.1 & \multicolumn{2}{|c|}{5.6} & \multicolumn{2}{|c|}{0.06} & 0.04 & \multicolumn{2}{|c|}{0.12} & \multicolumn{2}{|c|}{0.8} & 0.6 & \multicolumn{2}{|r|}{1.6} \\
\hline $\mathrm{CD}(\mathrm{P}=0.05)$ & \multicolumn{2}{|c|}{5.8} & NS & \multicolumn{2}{|c|}{11.5} & \multicolumn{2}{|c|}{0.12} & 0.09 & \multicolumn{2}{|c|}{0.25} & \multicolumn{2}{|c|}{1.6} & 1.2 & \multicolumn{2}{|r|}{3.3} \\
\hline
\end{tabular}

Table.4 Effect of biopriming on seed viability and microbial population in paddy

\begin{tabular}{|c|c|c|c|c|c|c|c|c|c|c|c|}
\hline \multirow[t]{2}{*}{ Treatments } & \multicolumn{3}{|c|}{ Seed germination $(\%)$} & \multicolumn{3}{|c|}{ Speed of germination } & \multicolumn{3}{|c|}{ Seedling length $(\mathrm{cm})$} & \multicolumn{2}{|c|}{$\begin{array}{l}\text { Microbial population (CFU } \\
\mathrm{g}^{-1} \text { of seed) }\end{array}$} \\
\hline & Initial & 3MAS & Mean & Initial & 3MAS & Mean & Initial & $3 \mathrm{MAS}$ & Mean & Initial & $3 \mathrm{MAS}$ \\
\hline T1 - Untreated Control & 82 & 81 & 81.5 & 5.5 & 5.5 & 5.5 & 28.5 & 27.7 & 28.1 & - & - \\
\hline $\begin{array}{l}\text { T2 - Seed soaking in Azospirillum } \\
\text { liquid culture @ 1:50 dilution for } \\
18 \mathrm{~h}\end{array}$ & 87 & 86 & 86.5 & 12.2 & 12.0 & 12.1 & 34.2 & 34.0 & 34.1 & $38 \times 10^{4}$ & $31 \times 10^{4}$ \\
\hline $\begin{array}{l}\text { T3 - Seed soaking in } \\
\text { Phosphobacteria liquid culture } \\
\text { @ 1:50 dilution for } 18 \mathrm{~h}\end{array}$ & 86 & 86 & 86.0 & 8.6 & 8.6 & 8.6 & 31.2 & 31.2 & 31.2 & $12 \times 10^{5}$ & $9 \times 10^{5}$ \\
\hline $\begin{array}{l}\text { T4 - Seed soaking in PPFM liquid } \\
\text { culture @ 1:100 dilution for } 18 \mathrm{~h}\end{array}$ & 91 & 91 & 91.0 & 14.3 & 13.8 & 14.0 & 33.9 & 33.3 & 33.6 & $8 \times 10^{4}$ & $2 \times 10^{4}$ \\
\hline Mean & 86.5 & 86.0 & & 10.2 & 9.9 & & 31.9 & 31.5 & & & \\
\hline $\begin{array}{l}\text { SEd } \\
\text { CD }(P=0.05)\end{array}$ & $\begin{array}{r}\text { Treatn } \\
1.2 \\
2.6\end{array}$ & & $\begin{array}{l}\text { Period } \\
0.8 \\
\text { NS }\end{array}$ & $\begin{array}{r}\text { Treatm } \\
0.4 \\
0.9\end{array}$ & & $\begin{array}{l}\text { Period } \\
0.3 \\
\text { NS }\end{array}$ & $\begin{array}{c}\text { Treatr } \\
0 .{ }^{2} \\
0.8\end{array}$ & & $\begin{array}{l}\text { Period } \\
0.2 \\
\text { NS }\end{array}$ & & \\
\hline
\end{tabular}


Pink pigmented facultative methylotroph mediate the cytokinin on germinating seeds (Holland and Polacco, 1994) and IAA on increased seedling vigour (Subhaswaraj et al., 2017). Bakonyi et al., (2013) opined that there is a positive effect of plant growth promoting bacteria (PGPB) on germination and growth by reason of excreting phytohormones and enhancing the nutrient mobilization from the seed.

It is concluded that the paddy seeds soaked in equal volume of liquid microbial cultures viz., Azospirillum or phosphobacteria @ 1:50 dilution for $18 \mathrm{~h}$ or PPFM liquid culture @ 1:100 dilution for $24 \mathrm{~h}$ have registered the higher germination and vigour. Pink pigmented facultative methylotroph has performed well among these microbial cultures in enhancing the seed germination. Also, the viability and vigour of bioprimed seeds were not much affected in three months storage. Phosphobacteria has recorded the maximum population $\left(12 \times 10^{5} \mathrm{CFU} \mathrm{g}^{-1}\right.$ of seed) in the paddy seed and PPFM has recorded the minimum $\left(8 \times 10^{4} \mathrm{CFU} \mathrm{g}^{-1}\right.$ of seed). However, the population range between $2 \times 10^{4}$ and $9 \times 10^{5}$ CFU $g^{-1}$ of seed was observed in three months storage.

\section{Acknowledgement}

The authors thank the University Grants Commission (UGC), New Delhi for financial assistance to carry out this work under the major research project.

\section{References}

Anitha, K. G. 2010. Enhancing seed germination of mono and dicotyledons through IAA production of PPFM. Trends Soil Sci. Plant Nutr. J., 1: 1418.

Bakonyi, N., S. Bott, E. Gajdos, A. Szabo, A. Jakab, B. Toth, P. Makleit and Sz.
Veres. 2013. Using biofertilizer to improve seed germination and early development of maize. Pol. J. Environ. Stud., 22 (6): 1595-1599.

Basra, S.M.A., M. Farooq and R. Tabassum. 2005. Physiological and biochemical aspects of seed vigor enhancement treatments in fine rice (Oryza sativa L.). Seed Sci. \& Technol. 33: 25-29.

Bradford, K.J. 1986. Manipulation of seed water relations via osmotic priming to improve germination under stress conditions. Hort. Sci. Alexandria, 21: 1105-1112.

Callan, N.W., D.E. Mathre and J.B. Miller. 1990. Bio-priming seed treatment for biological control of Pythium ultimum pre emergence damping off in sweet corn. Plant Dis., 74: 368-372.

Giri, G.S. and W.F. Schillinger. 2003. Seed priming in winter wheat for germination, emergence and yield. Crop Sci., 43: 2135-2141.

Gomathy, M., M. Thangaraju, S. Gunasekaran, N.O. Gopal and H. Gopal. 2008. Method and quantity of liquid formulation of phosphobacteria required for seed inoculation. Pak. J. Biol. Sci., 11: 86-91.

Graham, W. L., M.L. Bennett and A.S. Paau. 1987. Production of bacterial inoculants by direct fermentation on nutrient supplemented vermiculite. Applied Environ. Microbial., 53: 2138-2140.

Holland, M.A. and J.C. Polacco. 1994. PPFMs and other covert contaminants: is there more to plant physiology than just plant? Annu. Rev. Plant Physiol. Plant Mol. Biol., 45: 197-209.

Hynes, R.K., K.A. Craig, D. Covart, R.S. Smith and R.J. Rennie. 1995. Liquid rhizobial inoculants for lentil and field pea. J. Prod. Agric., 8: 547-552.

ISTA. 1999. International Rules for Seed Testing. Seed Science \& Technol., 27: 30-35. 
Jahuri, K.S. 2001. Preparation of legume inoculants and bacterization of seed: Training Manual on Biofertilizers. IARI, India, pp: 54-62.

Lin, J.M. and J.M. Sung. 2001. Pre-sowing treatment for improving emergence of bittergourd seedling under optimal and sub-optimal temperatures. Seed Sci. \& Technol., 29: 39-50.

Maguire, J. D. 1962. Speed of germinationaid selection and evaluation for seedling emergence and vigor. Crop Sci., 2: 176177.

Meena, K. K., M. Kumar, M.G. Kalyuzhnaya, M.S. Yandigeri, D.P. Singh, A.K. Saxena and D.K. Arora. 2012. Epiphytic pink-pigmented methylotrophic bacteria enhance germination and seedling growth of wheat (Triticum aestivum) by producing phytohormone. Antonie Van Leeuwenhoek, 101:777-786.

Nethery, A.A. 1991. Inoculant production with nonsterile carrier. In: Expert consultation on legume inoculant production and quality control. FAO, Rome, pp. 43-50.

Nkpwatt, D. A., M. Martina, T. Jochen, B. Mewes and S. Wilfried. 2006. Molecular interaction between Methylobacterium extorquens and seedlings: growth promotion, methanol consumption, and localization of the methanol emission site. J. Exp. Bot., 57 (15): 4025-4032.

Panse, V. G., and P.V. Sukhatme. 1967. Statistical Method for Agricultural Worker, ICAR Publication, New Delhi.

Subhaswaraj, P., R. Jobina, P. Parasuraman and B. Siddhardha. 2017. Plant growth promoting activity of Pink Pigmented Facultative MethylotrophMethylobacterium extorquens MM2 on Lycopersicon esculentum L. J. App. Biol. Biotech., 5 (1): 42-46.

\section{How to cite this article:}

Raja, K., K. Sivasubramaniam and Anandham, R. 2017. Manipulation of Seed Germination and Vigour by Biopriming with Liquid Microbial Cultures in Paddy (Oryza sativa L.). Int.J.Curr.Microbiol.App.Sci. 6(10): 1612-1618. doi: https://doi.org/10.20546/ijcmas.2017.610.193 